\title{
KORELASI ANTARA KESENJANGAN PEMBANGUNAN INFRASTRUKTUR JALAN DENGAN KESEJAHTERAAN PENDUDUK DI INDONESIA
}

\author{
Lisna Rahayu(1) \\ (1)Staf Pengajar, Program Studi Perencanaan Wilayah dan Kota, ITB. (lisnarahayu@gmail.com)
}

\begin{abstract}
Abstrak
Ketimpangan pembangunan jalan antar daerah di Indonesia diperkirakan berkorelasi dengan kesejahteraan masyarakat. Setuju atau tidak, harus kita akui bahwa salah satu indikator yang sering digunakan untuk mengukur kemakmuran adalah Produk Domestik Bruto (PDB). Namun, validitas PDB sebagai satu-satunya indikator kemakmuran suatu daerah masih diperdebatkan saat ini. Studi terbaru menunjukkan bahwa kemakmuran harus mencakup "aspek material" seperti sejahtera dalam arti memiliki akses pendidikan yang tinggi, fasilitas kesehatan atau daya beli yang tinggi, serta "aspek imaterial" seperti kebahagiaan masyarakat. Penelitian ini bertujuan untuk mengetahui apakah terdapat hubungan antara ketimpangan pembangunan jalan dengan tingkat kesejahteraan masyarakat di Indonesia, baik dari segi kesejahteraan material maupun immateril. Hasil analisis asosiasi menunjukkan bahwa infrastruktur jalan berkorelasi cukup erat dengan kemakmuran material tetapi tidak berkorelasi dengan kemakmuran immateriil.
\end{abstract}

Kata Kunci: Asosiasi, Disparitas Pembangunan Jalan, Korelasi, Kemakmuran,

\begin{abstract}
Disparity of road development between regions in Indonesia is predicted to correlate with people prosperity. Agree or not, we have to admit that an indicator that is often used to measure prosperity is Gross Domestic Product (GDP). However, the validity of GDP as the one and only indicator of a region's prosperity has been debated currently. Recent studies shows that prosperity should comprise "material aspects" such as being prosperous in terms of having high access to education, health facilities or having high purchasing power, and also "immaterial aspects" such as people happiness. This research aimed to identify whether there is correlation between imbalance road development with the level of people prosperity in Indonesia, both from the perspective of material and immaterial prosperity. The results of association analysis indicated that road infrastructure correlates quite closely with material prosperity but does not correlate with the immaterial prosperity.
\end{abstract}

Keywords: Association, Correlation, Disparity of Road Deelopment, Prosperity

\section{Pengantar}

Jalan merupakan urat nadi yang berperan penting dalam bidang ekonomi, sosial budaya, lingkungan hidup, politik, pertahanan dan keamanan (UU Jalan No 38 Tahun 2004). Ketersediaan infrastruktur jalan menjamin keterhubungan antar wilayah dalam menghubungkan pusat- pusat kegiatan serta mendukung terselenggaranya distribusi barang dan jasa (Kusbiantoro, 2007; Ortuzar and Willumsen, 2011). Beberapa penelitian telah membuktikan secara empiris bahwa ada korelasi kuat antara pembangunan jalan dan pembangunan ekonomi daerah (Banister and
Berechman, 2000; Ivanova and Masarova, 2013). Tingginya konektivitas jaringan jalan akan meningkatkan akses masyarakat terhadap fasilitas pendidikan, kesehatan, maupun pelayanan lainnya yang akan semakin lebih mudah dan terjangkau (Kurniawan dan Mulyono, 2005). Didasari pentingnya ketersediaan infrastruktur transportasi, Perserikatan Bangsa- Bangsa menjadikan penyediaan akses transportasi yang memadai sebagai salah satu fokus dalam Sustainable Develeopment Goals (SDGs). Tujuan ke - 9 SDGs menekankan perlunya pembangunan infrastruktur tangguh 
dengan indikator berupa ketersediaan akses terhadap jalan (BPS, 2015).

Pada kondisi eksisting, ketimpangan wilayah antar provinsi di Indonesia meningkat di dekade pertama desentralisasi (Talitha et al, 2019). Pembangunan di Indonesia cenderung belum merata, sebagian provinsi sudah berciri metropolitan yang cenderung mengalami mega urbanization seperti misalnya Bandung Metropolitan Area dan Jakarta Metropolitan Area (Firman, 2009; Indraprahasta, 2019), tetapi di sisi lain sebagian lain masih bersifat rural district yang banyak menjadi kantung kemiskinan (Friedman; 2003). Mengacu pada laporan World Bank (2006), disparitas antar wilayah di Indonesia tidak hanya dalam bentuk disparitas pendapatan tetapi juga sebagian besar meliputi disparitas akses terhadap beberapa layanan baik itu pendidikan, kesehatan dll, yang pada akhirnya berdampak terhadap disparitas pembangunan manusia antar wilayah. Adanya ketimpangan pembangunan ini diduga diakibatkan oleh belum meratanya ketersediaan infrastruktur jalan, terutama antara bagian barat Indonesia yang telah didominasi oleh perkotaan yang bercirikan metropolitan dengan bagian timur Indonesia yang cenderung masih didominasi oleh kawasan perdesaan. Sebagai ilustrasi, pada tahun 2017 Provinsi Jawa Barat dengan luas $35.377,76 \mathrm{Km}^{2}$ atau sekitar $1,85 \%$ dari luas wilayah Indonesia memiliki panjang jalan $27.143 \mathrm{Km}$, sedangkan Provinsi Papua dengan luas wilayah $319.036 \mathrm{~km}^{2}$ atau sekitar $16,64 \%$ dari luas wilayah Indonesia memiliki panjang jalan $18.697 \mathrm{Km}$ (BPS, 2018).

Meskipun ketersediaan infrastruktur jalan berkorelasi erat dengan karakteristik wilayah, misal sebagian area lebih cocok menggunakan transportasi sungai/ laut dan udara, tetapi tidak dapat dipungkiri bahwa transportasi darat tetap berperan vital mengingat transportasi laut dan udara memiliki kelemahan yaitu tidak dapat bersifat door to door dan tetap membutuhkan transportasi darat sebagai transportasi awal dan akhir. Diduga tidak meratanya aksesibilitas jaringan jalan antara wilayah Indonesia bagian barat dan timur berpengaruh terhadap tingkat kesejahteraan penduduk. Hipotesis ini dibangun berdasarkan penelitian sebelumnya di negara lain yang menunjukkan bahwa ketersediaan jaringan infrastruktur jalan akan berdampak terhadap pembangunan ekonomi, sosial dan budaya suatu wilayah (Porter, 2002; Maparu and Mazumder, 2017; Arimah, 2017; Li et al; 2018).
Hakikatnya pembangunan adalah bagi kesejahteraan penduduk, dan indikator yang relevan serta dapat merepresentasikan kesejahteraan penduduk adalah Indeks Pembangunan Manusia (IPM). IPM merupakan indeks komposit yang memotret kondisi pendidikan, kesehatan dan daya beli penduduk (UNDP, 2019 1990; BPS, 2020). Indikator ini dinilai reprsentatif untuk memotret tingkat kesejahteraan penduduk. Meskipun pada ekonomi makro, perekonomian wilayah seringkali diukur menggunakan PDRB, pada penelitian ini indikator ini tidak digunakan sebab dinilai kurang representatif, dan kadangkala bias terutama bagi daerah penghasil sumber daya alam yang tinggi. Daerah-daerah tersebut umumnya memiliki PDRB yang tinggi tetapi tidak jelas sektor mana yang mendapat manfaat dari tingginya PDRB tersebut serta apakah meningkatkan kesejahteraan masyarakat secara keseluruhan atau hanya mensejahterakan golongan masyarakat tertentu saja cenderung kompleks atau sukar untuk dapat diidentifikasi. PDRB memasukan semua barang dan jasa sebagai hasil dari kegiatan-kegiatan ekonomi yang beroperasi di suatu wilayah tanpa memperhatikan apakah faktor produksinya tersebut berasal dari atau dimiliki oleh penduduk wilayah tersebut atau tidak (BPS, 2019). Pada kenyataannya sebagian dari faktor produksi yang digunakan dalam kegiatan produksi di suatu daerah berasal dari daerah lain atau dari luar negeri, demikian juga sebaliknya faktor produksi yang dimiliki oleh penduduk daerah tersebut mungkin pula menjadi input produksi di daerah lain atau di luar negeri sehingga sulit untuk melacak apakah peningkatan PDRB suatu wilayah ini betul-betul mensejahterakan masyarakat lokal atau tidak. Sebagai contoh sederhana, misal pada penggunaan tenaga kerja sebagai salah satu faktor produksi. Umumnya area yang kaya sumber daya alam, katakanlah suatu perusahaan pertambangan di Pulau Papua mendatangkan tenaga kerja dari Pulau lain di Indonesia atau bahkan warga negara asing dari luar negeri. Dalam perhitungan PDRB, upah tenaga kerja migran ini turut diperhitungkan sebagai bagian dari PDRB wilayah tersebut padahal pada kenyataannya sebagian besar upah tersebut kemungkinan mengalir ke tempat asal para pekerja.

Didasari pertimbangan di atas, maka indikator kesejahteraan yang digunakan dalam penelitian ini lebih dititik beratkan pada indikator IPM. Tidak meratanya aksesibilitas jaringan jalan antara wilayah Indonesia bagian 
barat dan timur diduga berkorelasi dengan nilai IPM. Diduga ketersediaan akses jalan akan berbanding lurus dengan nilai IPM. Tapi apakah korelasi tersebut juga berlaku terhadap hal-hal yang bersifat immaterial seperti kebahagiaan penduduk? Mengingat kesejahteraan tidak saja meliputi aspek yang bersifat konkrit/materiil seperti misalnya sejahtera dalam hal memiliki akses yang tinggi terhadap pendidikan, kesehatan dan memiliki daya beli yang tinggi, tetapi juga dapat meliputi aspek yang sifatnya immateril seperti tingkat kebahagian (Decleve and Pereira, 2019; Delhey and Kroll, 2013; Dipietro and Anoruo, 2006). Dengan demikian, perlu pula mengidentifikasi korelasi antara ketersediaan infrastruktur jaringan jalan dengan kesejahteraan penduduk yang bersifat immaterial, disamping mengidentifikasi hubungannya dengan kesejahteraan yang sifatnya konkrit/Materiill.

Dengan demikian, pertanyaan penelitian pada studi ini meliputi 2 pertanyaan penelitian. Pertama, "Apakah terdapat kesenjangan (perbedaan rata- rata) dalam ketersediaan infrastruktur jalan antara pulau-pulau yang didominasi perkotaan dan perdesaan di Indonesia?" Dan kedua "Adakah hubungan antara kondisi kesenjangan ketersediaan akses jalan tersebut dengan tingkat kesejahteraan penduduk, baik kesejahteraan yang sifatnya materiil maupun immaterial?"

Untuk menjawab pertanyaan penelitian diatas, maka tujuan penelitian ini adalah untuk mengidentifikasi kesenjangan (perbedaan rata-rata) dalam ketersediaan infrastruktur jalan dan mengidentifikasi hubungan antara kesenjangan tersebut terhadap kesejahteraan penduduk di Indonesia, baik kesejahteraan yang sifatnya materiil maupun immaterial.

\section{KAJIAN PUSTAKA}

a. Konseptualisasi Kesejahteraan

Kesejahteraan menyiratkan suatu keadaan/kondisi dimana penduduk dapat menikmati kehidupan yang makmur, memuaskan, dimana kemajuan ekonomi, sosial dan teknologi terjadi secara selaras dengan kualitas lingkungan (PBB, 2015). Di dalam report SDGs tahun 2019 Perserikatan Bangsa - Bangsa (PBB) menegaskan bahwa sejak ditetapkannya Sustainable Development Goals pada tahun 2015, PBB telah menyediakan cetak biru bagi kesejahteraan masyarakat dunia secara berkelanjutan, untuk membangun dunia di mana semua orang diharapkan dapat hidup secara produktif, vibrant, aman dan damai. Menurut UN-Habitat (2012), kota yang sejahtera dikonseptualisasikan sebagai "The Wheel of Urban Prosperity", yang menganalogikan suatu kesejahteraan sebagai sebuah roda yang terdiri atas lima komponen, yang mana kesejahteraan ini akan tercapai jika roda terus berputar dengan adanya keseimbangan antara kelima komponen sumbu penopangnya atau dengan kata lain suatu kota dikatakan sejahtera jika mampu memenuhi lima aspek bagi penduduknya. Kelima aspek tersebut meliputi:

1. Productivity: Kota yang sejahtera harus mampu memfasilitasi terwujudnya produktivitas perkotaan yang diharapkan mampu mendorong pertumbuhan dan pembangunan ekonomi perkotaan;

2. Infrastructure: Kota yang sejahtera harus memastikan ketersediaan infrastruktur beserta sarananya bagi seluruh penduduk, baik infrastruktur transportasi, air bersih, air limbah, drainase, maupun listrik dan telekomunikasi.

3. Quality of life: Kota yang sejahtera harus mampu memberikan kehidupan berkualitas bagi penduduknya, menyediakan layanan sosial untuk meningkatkan standar kehidupan dan menjamin keselamatan dan keamanan, seperti tersedianya sarana pendidikan, kesehatan, perdagangan dan sebagainya.

4. Equity and social inclusion: Kota yang sejahtera harus mampu menjamin tidak adanya disparitas/ ketimpangan antar penduduk dan senantiasa mengikut sertakan seluruh penduduk tanpa ada yang termarginalkan.

5. Environmental sustainability: Kota yang mampu menjamin terwujudnya kesejahteraan ekonomi tanpa mengorbankan keberlanjutan kualitas lingkungan. 


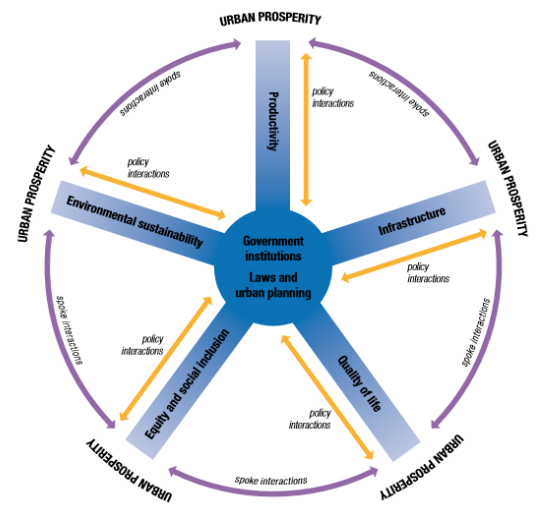

Gambar 1.The Wheel of Urban Prosperity (UN Habitat, 2012)

Pada kondisi eksisting kecenderungan yang berjalan selama ini tidak dapat dipungkiri bahwa untuk mengukur keberhasilan dan kesejahteraan suatu bangsa indikator yang selalu digunakan adalah Produk Domestik Bruto (Fox, 2012). Sejumlah dimensi kesejahteraan yang sifatnya non-ekonomi telah diusulkan secara sistematis, dimulai dari gerakan indikator sosial pada akhir tahun 1960-an dan 1970-an, yang diusulkan untuk melengkapi aspek ekonomi sebagai indikator kemakmuran dan kemajuan suatu negara (Land and Michalos, 2018). Validitas PDB sebagai satu-satunya ukuran kesejahteraan suatu wilayah telah banyak diperdebatkan, kecenderungan yang terjadi saat ini terdapat peningkatan concern untuk mendefinisikan ulang indikator pengukur kesejahteraan agar dapat mampu menjelaskan kesejahteraan dalam konteks yang lebih luas yang mampu menggambarkan kesejahteraan yang lebih baik, seperti misalnya Human Development Index (HDI), Index of Sustainable Economic Welfare (ISEW) and the Genuine Progress Indicator (GPI) (Kalimeris, 2020). The Club of Rome berargumentasi bahwa jika mengikuti konsep Sustainable Development, kesejahteraan sebagai situasi dimana individu atau kelompok individu meningkat secara teratur dan dengan cara yang berkelanjutan dan inklusif secara sosial, maka kesejahteraan mencakup baik yang bersifat materil seperti misalnya konsumsi, kesehatan dan hal yang bersifat immaterial seperti kebebasan memilih, demokrasi, keadilan dalam pendapatan, akses ke modal sosial dan budaya (Decleve and Pereira, 2019). Sejalan dengan argumentasi ini, banyak penelitian yang telah mengkonseptualisasikan aspek yang bersifat immaterial sebagai indikator dari suatu kesejahteraan, seperti msialnya dalam penelitian Musa et al (2018), Kushlev (2017), dan Trkulja (2007) yang mengindikasikan indikator Happiness Index (Indeks Kebahagiaan) sebagai salah satu ukuran yang lebih relevan merepresentasikan kesejahteraan penduduk.

Jika dirunut dalam suatu rangkuman, indikator diluar GDP yang sesuai untuk digunakan sebagai indikator kesejahteraan ditampilkan pada Tabel 1 berikut. Meninjau hasil literature review, dapat disimpulkan bahwa GDP sudah kurang relevan untuk digunakan mengukur kesejahteraan. Untuk mengukur kesejahteraan penduduk, sebaiknya menggunakan aspek yang bersifat material dan immaterial. Indikator berisfat material yang telah diukur secara berkala dan datanya tersedia di Indonesia adalah Human Development Index atau Indeks Pembangunan Manusia (IPM) yang merupakan komposit terhadap pengukuran tingkat pendidikan, tingkat kesehatan, dan daya beli penduduk. Adapun untuk indikator yang bersifat immaterial, indikator yang tersedia di Indonesia dan telah dilakukan pengukuran oleh BPS adalah indikator Indeks Kebahagiaan. Dengan demikian, dalam penelitian ini indikator kesejahteraan yang digunakan difokuskan kepada indikator IPM untuk indikator yang bersifat material dan indikator Indeks Kebahagiaan untuk indikator yang sifatnya immaterial.

\section{b. Korelasi Ketersediaan Infrastruktur dengan Kesejahteraan}

Hasil penelitian sebelumnya di beberapa negara menunjukkan terdapat korelasi antara ketersediaan infrastruktur dengan tingkat kesejahteraan penduduk. Penelitian Arimah (2017) menunjukkan infrastruktur merupakan katalis bagi kesejahteraan kota-kota di Afrika. Menurut Arimah, peran kontribusi infrastruktur terhadap kemakmuran kota-kota Afrika telah mendorong pertumbuhan ekonomi; memfasilitasi mobilitas perkotaan; memastikan akses yang lebih besar ke kesehatan dan pendidikan; meningkatkan kualitas hidup; membimbing atau mengarahkan pertumbuhan kota; meningkatkan kualitas lingkungan; mengurangi insiden dan kemiskinan; dan mengurangi kesenjangan spasial, khususnya di kota-kota dengan daerah periurban yang tidak terlayani. Penelitian Porter (2002) di subsaharna afrika menunjukkan bahwa tingkat kemiskinan dan kesehatan penduduk pada 
populasi pedesaan di Afrika diperparah oleh akses fisik yang buruk. Penelitian di India, dengan menggunakan pendekatan kointegrasi dan uji kausalitas Granger menunjukkan bahwa road density telah ditemukan memiliki hubungan jangka panjang dengan pembangunan ekonomi (Maparu and Mazumder, 2017). Penelitian di Yun-GuiChuan region dan Jiang-Zhe-Hu region, China menunjukkan bahwa infrastruktur jalan akan berpengaruh terhadap ekonomi lokal dengan level yang berbeda-beda tergantung pada karakteristik wilayah (Li et al, 2018). Mengacu pada penelitian-penelitian di atas, jelas bahwa terdapat korelasi antara ketersediaan infrastruktur, khususnya infrastruktur jalan dengan kesejahteraan penduduk.

\section{METODOLOGI \\ a. Metode Pengumpulan Data}

Pengumpulan data dalam penelitian ini dilakukan melalui survei data sekunder berupa studi literatur, dan pengumpulan data dan informasi yang sudah didokumentasikan oleh Badan Pusat Statistik. Data yang digunakan meliputi 4 variabel. Dua variabel diantaranya yaitu variabel panjang jalan per provinsi dan variabel luas wilayah per provinsi menjadi data input bagi variabel rasio panjang jalan terhadap luas wilayah. Tahun data yang digunakan untuk kedua variabel yaitu data tahun 2017. Dua variabel lainnya yang digunakan dalam penelitian ini yaitu variabel Indeks Pembangunan Manusia (IPM) dan Indeks Kebahagiaan dengan tahun data tahun 2017.

\section{b. Metode Analisis Data}

Analisis data dalam penelitian ini dilakukan menggunakan analisis statistik asosiasi menggunakan Analisis of Variance (ANOVA) dan analisis koefisien korelasi $r$ pearson. Analisis asosiasi digunakan untuk mengidentifikasi korelasi antara dua atau lebih variabel. Mengingat data yang digunakan dapat diklasifikasikan sebagai data interval rasio, maka analisis korelasi $r$ pearson dan anova dalam hal ini tidak hanya dapat digunakan untuk mengidentifikasi keberadaan hubungan, tetapi juga dapat digunakan untuk mengidentifikasi keeratan hubungan dan arah hubungan (Healey, 2012).

\section{Diskusi \\ a. Ketimpangan Ketersediaan Infrastruktur Jalan antar Pulau dan antar Provinsi di Indonesia}

Diduga tidak meratanya aksesibilitas jaringan jalan antara wilayah Indonesia bagian barat dan timur berpengaruh terhadap tingkat kesejahteraan penduduk. Untuk mengidentifikasi hal tersebut, dilakukan analisis korelasi antara lokasi geografis seluruh wilayah Indonesia dengan ketersediaan infrastruktur jalan di Indonesia. Pembagian lokasi geografis dilakukan berdasarkan provinsi yang kemudian diklasifikasikan berdasarkan pulau, yakni meliputi Pulau Jawa Bali, Pulau Sumatera, Pulau Kalimantan, Pulau Sulawesi dan Pulau lainnya yang meliputi area Nusa Tenggara, Maluku dan Papua. Adapun indikator ketersediaan jalan yang digunakan adalah rasio panjang jalan (dalam $\mathrm{Km}$ ) terhadap luas wilayah provinsi (dalam $\mathrm{Km}^{2}$ ). Distribusi rasio panjang jalan terhadap luas wilayah di setiap provinsi dan klasifikasi pulau disajikan pada tabel 1. Untuk mengidentifikasi adanya kesenjangan/perbedaan rata-rata rasio panjang jalan terhadap luas wilayah provinsi di tiap pulau di Indonesia dilakukan analisis of variance (ANOVA). Dalam pengujian ini ditetapkan asumsi dan hipotesa sebagai berikut:

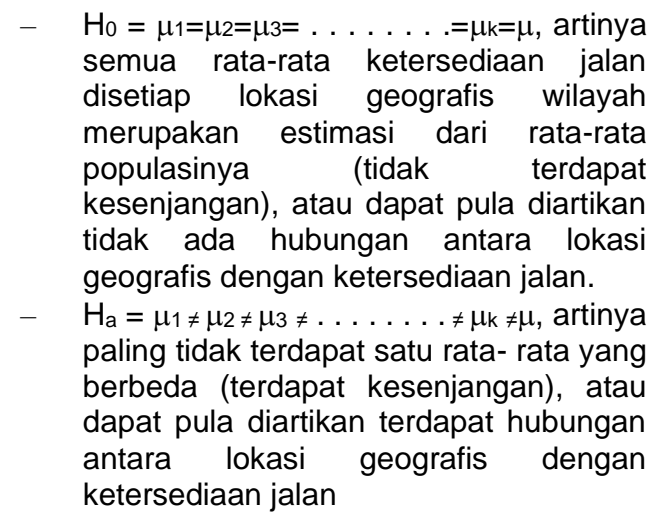

Dengan tingkat kepercayaan $90 \%$, dengan jumlah populasi sebanyak 34 provinsi dalam 5 kategori pulau, maka degree of freedom within category (Dfw) $=\mathrm{N}-\mathrm{k}=34-5$ $=29$, sedangkan nilai Degree of Freedom between category $(\mathrm{Dfb})=\mathrm{k}-1=5-1=4$, maka nilai $F$ berdasarkan tabel $F$ yang menjadi batas wilayah kritis adalah 2,15. Berdasarkan hasil uji anova, diperoleh nilai $F$ hitung sebesar 
2,22 sebagaimana ditunjukkan oleh hasil uji annova pada Tabel 2. Jika disandingkan dengan nilai $F$ tabel, maka nilai $F$ hitung lebih besar dari nilai $\mathrm{F}$ tabel, dengan demikian $\mathrm{H}_{0}$ ditolak, dan $\mathrm{H}_{1}$ diterima, artinya terdapat perbedaan rata-rata/kesenjangan ketersediaan infrastruktur jalan pada setiap kategori pulau di Indonesia, atau dapat pula diartikan terdapat hubungan antara lokasi geografis dengan ketersediaan jalan.

Jika diamati per kategori pulau, teridentifikasi adanya perbedaan yang signifikan pada rata-rata rasio panjang jalan terhadap luas wilayah provinsi di setiap Pulau. Pulau Jawa - Bali menduduki urutan tertinggi dengan rasio panjang jalan terhadap luas wilayah tertinggi di Indonesia. Hal ini tidak dapat dipisahkan dari karakteristik Pulau Jawa-Bali sendiri yang didominasi oleh kawasan perkotaan. Pada kondisi eksisting, Pulau Jawa-Bali menjadi rumah bagi 4 metropolitan area yaitu Jabodetabek (Jakarta, Bogor, Depok, Tangerang, Bekasi), Bandung
Raya, Gerbang kertosusilo (Gresik, Bangkalan, Mojokero, Surabaya, Sidoarjo dan Lamongan), dan Kedung sepur (Kendal, Demak, semarang, Salatiga, dan Grobogan) (Wajdi et al, 2017). Sebaliknya Pulau Kalimantan menjadi pulau dengan rasio panjang jalan terhadap luas wilayah provinsi yang terkecil di Indonesia. Hal ini diakibatkan oleh luas wilayah Kalimantan yang signifikan dibanding pulau lainnya, yakni sekitar $28 \%$ dari luas daratan Indonesia.

Jika diidentifikasi antar provinsi dalam suatu pulau, terdapat perbedaan rasio panjang jalan terhadap luas wilayah yang sangat signifikan. Pada Pulau Jawa-Bali misalnya, Provinsi DKI Jakarta menjadi provinsi dengan rasio Panjang jalan terhadap luas wilayah tertinggi dengan angka rasio sebesar 10,138. Angka ini lebih tinggi lebih dari 5 kali angka rasio provinsi lainnya di Pulau Jawa Bali yang nilainya berkisar.

Tabel 2. Hasil Uji Annova

\begin{tabular}{|c|c|c|c|c|c|c|c|c|c|c|c|c|c|}
\hline \multicolumn{2}{|c|}{ Pulau Jawa-Bali } & \multicolumn{3}{|c|}{ Pulau Sumatera } & \multicolumn{3}{|c|}{ Kalimantan } & \multicolumn{3}{|c|}{ Sulawesi } & \multicolumn{3}{|c|}{ Pulau Lainnya } \\
\hline No Provinsi & $\begin{array}{c}\text { Rasio } \\
\text { Jalan }\end{array}$ & No & Provinsi & $\begin{array}{c}\text { Rasio } \\
\text { Jalan }\end{array}$ & No & Provinsi & $\begin{array}{l}\text { Rasio } \\
\text { Jalan }\end{array}$ & No & Provinsi & $\begin{array}{l}\text { Rasio } \\
\text { Jalan }\end{array}$ & No & Provinsi & $\begin{array}{l}\text { Rasio } \\
\text { Jalan }\end{array}$ \\
\hline 1 DKI Jakarta & 10,138 & 1 & Aceh & 0,414 & 1 & Kalimantan Barat & 0,124 & 1 & Sulawesi Utara & 0,710 & 1 & Nusa Tenggara Barat & 0,459 \\
\hline 2 Jawa Barat & 0,763 & 2 & Sumatera Utara & 0,542 & 2 & Kalaimantan Tengah & 0,117 & 2 & Sulawesi Tengah & 0,268 & 2 & Nusa Tenggara Timur & 0,476 \\
\hline 3 Jawa Tengah & 0,927 & 3 & Sumatera Barat & 0,537 & 3 & Kalimantan Selatan & 0,351 & 3 & Sulawesi Selatan & 0,657 & 3 & Maluku & 0,218 \\
\hline 4 DI Yogyakarta & 1,397 & 4 & Riau & 0,287 & 4 & Kalimantan Timur & 0,103 & 4 & Sulawesi Tenggara & 0,343 & 4 & Maluku Utara & 0,232 \\
\hline 5 Jawa Timur & 0,858 & 5 & Jambi & 0,260 & 5 & Kalimantan Utara & 0,042 & 5 & Gorontalo & 0,488 & 5 & Papua Barat & 0,115 \\
\hline 6 Banten & 0,717 & 6 & Sumatera Selatan & 0,210 & & & & & Sulawesi Barat & 0,343 & & Papua & 0,068 \\
\hline \multirow[t]{4}{*}{7 Bali } & 0,501 & 7 & Bengkulu & 0,462 & & & & & & & & & \\
\hline & & 8 & Lampung & 0,608 & & & & & & & & & \\
\hline & & & $\begin{array}{l}\text { Kepulauan } \\
\text { Bangka Belitung }\end{array}$ & 0.334 & & & & & & & & & \\
\hline & & 10 & Kepulauan Riau & 0,693 & & & & & & & & & \\
\hline Rata- Rata Kriteria & 2,329 & & & 0,435 & & & 0,147 & & & 0,468 & & & 0,261 \\
\hline Rata - Rata Total & 0,728 & & & & & & & & & & & & \\
\hline ssw & 71,724 & & & & & & & & & & & & \\
\hline SSB & 22,190 & & & & & & & & & & & & \\
\hline MSW & 2,494 & & & & & & & & & & & & \\
\hline MSB & 5,548 & & & & & & & & & & & & \\
\hline F Statistik & 2,224 & & & & & & & & & & & & \\
\hline F Tabel $(a 0,01)$ & 2,15 & & & & & & & & & & & & \\
\hline
\end{tabular}

Sumber: Hasil Analisis, 2020

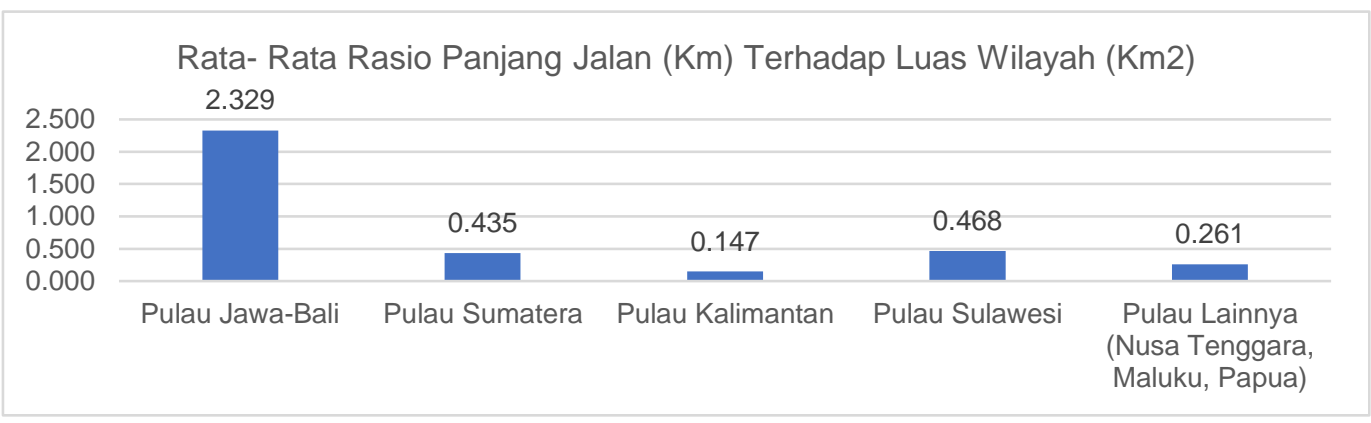

Gambar 2. Rata- Rata Rasio Panjang Jalan Terhadap Luas Wilayah Provinsi, 2017

Sumber: Hasil Analisis, 2020 
Jika diidentifikasi antar provinsi dalam suatu pulau, terdapat perbedaan rasio panjang jalan terhadap luas wilayah yang sangat signifikan. Pada Pulau Jawa-Bali misalnya, Provinsi DKI Jakarta menjadi provinsi dengan rasio panjang jalan terhadap luas wilayah tertinggi dengan angka rasio sebesar 10,138. Angka ini lebih tinggi lebih dari 5 kali angka rasio provinsi lainnya di Pulau Jawa Bali yang nilainya berkisar antara 0,7 sd 1,5. Hasil ini mengindikasikan bahwa konektivitas dalam Provinsi DKI Jakarta cenderung tinggi, dimana seluruh area cenderung sudah terkoneksi dengan jaringan jalan. Namun demikian hasil ini juga mengindikasikan adanya ketimpangan pembangunan infrastruktur jalan di Pulau Jawa-Bali yang mana kecenderungan pembangunan saat ini cenderung berpusat di DKI Jakarta.

Berbeda dengan Pulau Jawa - Bali, angka rasio panjang jalan terhadap luas wilayah pada beberapa provinsi cenderung merata dengan selisih rentang yang tidak terlalu tinggi. Provinsi Sumatera Selatan sebagai provinsi dengan angka rasio terrendah memiliki nilai angka rasio sebesar 0,210 sedangkan Kepulauan Riau merupakan provinsi dengan angka rasio tertinggi dengan nilai angka rasio sebesar 0,693. Hal ini tidak terlepas dari karakteristik Kepulauan Riau yang cenderung telah tumbuh sebagai kawasan perkotaan, terlebih lagi Kepulauan Riau menjadi rumah bagi Batam yang merupakan salah satu kawasan ekonomi khusus nasional. Di sisi lain, meskipun di Provinsi Sumatera Selatan terdapat Palembang sebagai salah satu kota terbesar di Indonesia, tetapi Provinsi Sumatera Selatan memilki luas wilayah paling tinggi di Pulau Sumatera dengan keberadaan hutan lindung yang cukup signifikan.

Trend yang sama terjadi pada Pulau Sulawesi, dimana angka rasio cenderung merata dengan rentang angka rasio antar provinsi terendah hingga tertinggi berkisar antara 0,268 hingga 0,710. Sulawesi Tengah merupakan provinsi dengan angka rasio terrendah sedangkan Sulawesi Utara merupakan provinsi dengan angka rasio tertinggi, yang kemudian disusul oleh Sulawesi Selatan pada posisi kedua. Tingginya rasio panjang jalan terhadap luas wilayah di Provinsi Sulawesi Utara dan Sulawesi Selatan diduga diakibatkan oleh urbanisasi wilayah dikedua Provinsi, yang mana kedua provinsi merupakan rumah bagi kota-kota besar seperti misalnya Manado di Sulawesi Utara dan Makassar di Sulawesi Selatan. Menyerupai trend di Pulau Jawa - Bali, Pulau Kalimantan memiliki perbedaan rentang rasio yang tinggi antar provinsi. Kalimantan Selatan menjadi provinsi dengan angka rasio tertinggi dengan nilai angka rasio sebesar 0,351 , sedangkan Kalimantan Utara memiliki angka rasio tertinggi dengan nilai 0,042 . Jika dibandingkan dengan rasio provinsi - provinsi lain di Pulau lain di Pulau Kalimantan cenderung rendah. Hal ini diakibatkan karena luasnya area Provinsi di pulau ini yang didominasi oleh kawasan lindung, sehingga pembangunan infrastruktur jalan hanya terkonsentrasi di beberapa titik area provinsi. 


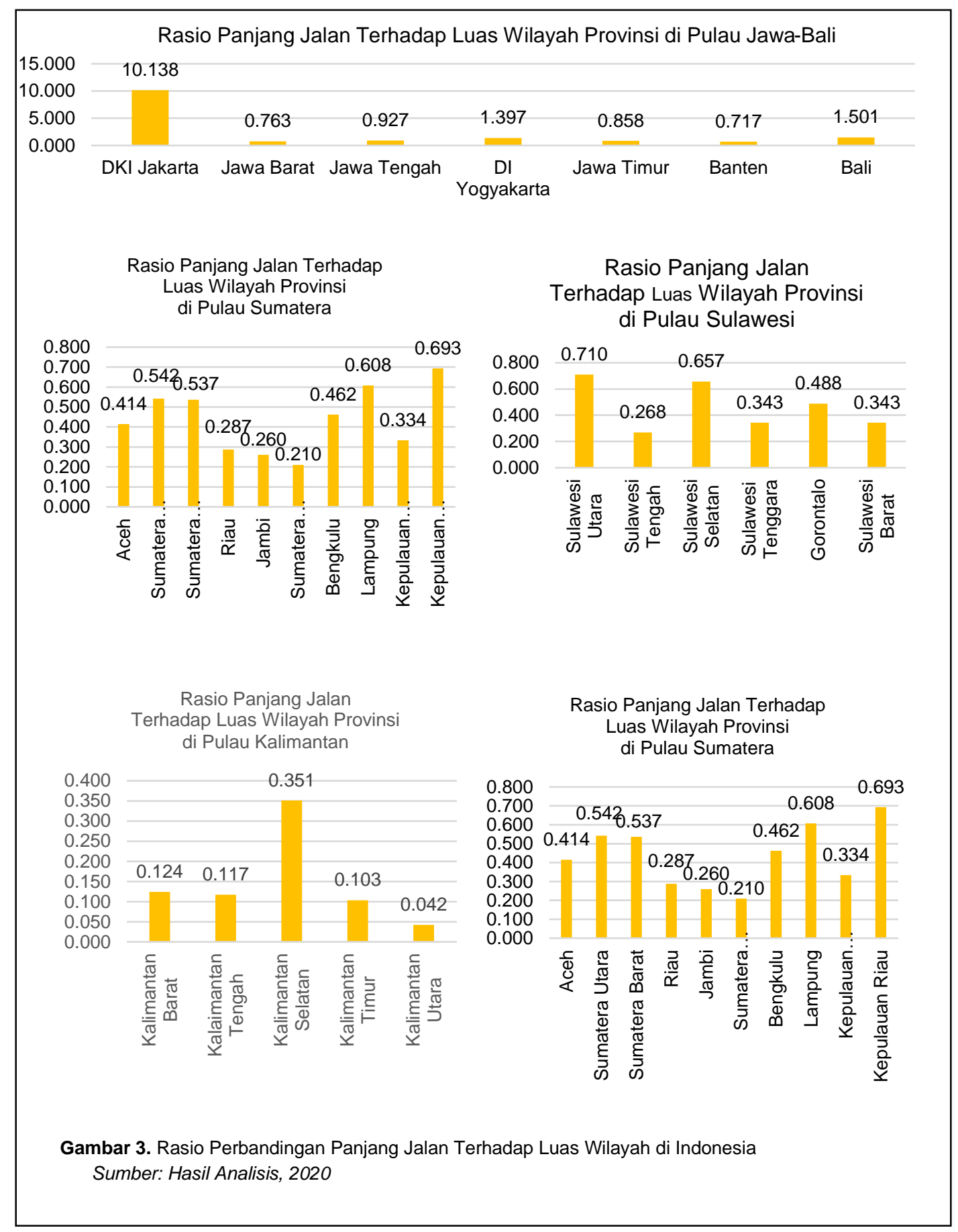


Gugusan pulau Nusa Tenggara, Maluku dan Papua memiliki kecenderungan ketimpangan yang cukup tinggi dalam hal ketersediaan infrastruktur jalan. Nusa Tenggara Barat dan Nusa Tenggara Timur menjadi provinsi-provinsi dengan angka rasio panjang jalan terhadap luas wilayah tertinggi di gugusan pulau di wilayah timur Indonesia ini dengan nilai angka rasio 0,459 dan 0,476. Sedangkan Papua menjadi provinsi dengan angka rasio terrendah dengan nilai angka rasio 0,068 .

Rendahnya angka rasio ketersediaan infrastrktur jalan di Provinsi Papua diakibatkan oleh dominasi kawasan Papua yang merupakan kawasan konservasi serta rendahnya aksesibilitas di Provinsi ini yang diakibatkan oleh kontur papua yang sulit dilalui oleh transportasi darat, sehingga konektivitas antar wilayah di provinsi ini cenderung rendah.

\section{b. Hubungan Ketersediaan Infrastruktur Jalan Terhadap Kesejahteraan Penduduk}

Tabel 2. Tabel Korelasi Pearson Keterkaitan antara Ketersediaan Infrastruktur Jalandengan Tingkat Kesejahteraan

\begin{tabular}{|c|c|c|c|c|}
\hline \multicolumn{5}{|l|}{ Correlations } \\
\hline & & Rasio_Jalan & IPM & Indeks_Kebahagiaan \\
\hline \multirow[t]{3}{*}{ Rasio_Jalan } & $\begin{array}{l}\text { Pearson } \\
\text { Correlation }\end{array}$ & $1=$ &, $493^{* *}$ & 0,253 \\
\hline & Sig. (2-tailed) & & 0,003 & 0,149 \\
\hline & $\mathrm{N}$ & 34 & 34 & 34 \\
\hline \multirow[t]{3}{*}{ IPM } & $\begin{array}{l}\text { Pearson } \\
\text { Correlation }\end{array}$ &, $493^{\star *}$ & 1 &, $492^{* *}$ \\
\hline & Sig. (2-tailed) & 0,003 & & 0,003 \\
\hline & $\mathrm{N}$ & 34 & 34 & 34 \\
\hline \multirow[t]{3}{*}{ Indeks_Kebahagiaan } & $\begin{array}{l}\text { Pearson } \\
\text { Correlation }\end{array}$ & 0,253 &, $492^{\star \star}$ & 1 \\
\hline & Sig. (2-tailed) & 0,149 & 0,003 & \\
\hline & $\mathrm{N}$ & 34 & 34 & 34 \\
\hline
\end{tabular}

**. Correlation is significant at the 0.01 level (2-tailed).

Sumber: Hasil Analisis, 2020

Berdasarkan hasil uji korelasi Pearson diperoleh hasil bahwa terdapat hubungan yang signifikan antara variabel rasio panjang jalan terhadap luas. provinsi dengan variabel IPM pada level $\alpha 1 \%$ atau tingkat kepercayaan $99 \%$ pada uji dua sisi, yang mana hasil pengujian menunjukkan nilai pearson correlation $(r)$ sebesar 0,493 . Nilai ini lebih besar dibandingkan nilai $r$ tabel untuk a $1 \%$ dan $\mathrm{df}=32$ yang hanya berkisar 0,4357 . Nilai $r$ statistik yang lebih tinggi dibandingkan nilai $r$
Mengacu pada (Decleve and Pereira, 2019), kesejahteraan dapat dilihat dalam dua konteks. Pertama, kesejahteraan yang sifatnya material seperti memiliki tingkat pendidikan yang tinggi, derajat kesehatan yang tinggi, serta memiliki daya beli yang tinggi. Dalam penelitian ini, kesejahteraan tersebut akan diwakili oleh indikator Indeks Pembangunan Manusia (IPM). Kedua, kesejahteraan yang sifatnya immaterial yang sulit untuk diukur, seperti misalnya tingkat kebahagiaan. Dalam penelitian ini, kesejahteraan yang bersifat immaterial diwakili oleh indikator Indeks kebahagian. Dalam mengindentifikasi apakah terdapat kaitan antara ketersediaan infrastruktur jalan dengan kesejahteraan penduduk di Indonesia baik yang sifatnya material dan immaterial dilakukan analisis Korelasi Pearson. Dengan menggunakan bantuan software SPSS, diperoleh hasil hubungan antara ketersediaan jalan dengan tingkat kesejahteraan penduduk perprovinsi di Indonesia sebagai berikut. 
diperoleh $r^{2}$ sebesar 24,30\%. Nilai $r^{2}$ ini mengindikasikan bahwa 24,30 \% variansi pada nilai IPM dapat dijelaskan oleh rasio ketersediaan jalan disetiap provinsi. Angka ini cukup menunjukkan betapa pentingnya peran infrastruktur jalan dalam mendukun konektivitas sehingga masyarakat dapat mengakses fasilitas pendidikan, fasilitas kesehatan, tempat kerja, dan pasar untuk memenuhi keperluan komoditas penduduk sehingga secara tidak langsung turut berperan dalam menentukan indeks pendidikan, indeks kesehatan, dan indeks daya beli yang dikompositkan dalam suatu indeks IPM.

Jika dilihat berdasarkan pulau, dapat diamati bahwa provinsi Jawa - Bali yang merupakan provinsi dengan angka rasio panjang jalan terhadap luas wilayah tertinggi (lihat gambar 2) juga memiliki rata- rata IPM tertinggi dibandingkan pulau lainnya (lihat gambar 4). Pulau Sumatera dan Pulau Sulawesi yang memiliki urutan rasio panjang jalan tehadap luas wilayah tertinggi setelah DKI Jakarta, jika ditinjau dari segi IPM juga memiliki peringkat yang hampir sama, dimana Pulau Sumatera menduduki peringkat ke-2 dan Pulau Sulawesi menduduki peringkat ke-
4. Hal yang tampak kontras terjadi pada Pulau Kalimantan, ditinjau berdasarkan variabel rasio panjang jalan terhadap luas wilayah Pulau Kalimantan memiliki angka rasio terrendah, namun demikian jika dilihat berdasarkan IPM penduduk di Pulau Kalimanatan cenderung memiliki rata-rata IPM yang tergolong tinggi dan menduduki peringkat ke-3 dibanding pulau-pulau lain di Indonesia. Hal ini diduga diakibatkan karena pembangunan Kalimantan cenderung terkonsentrasi di titik-titik tertentu. Luas wilayah Kalimantan yang didominasi oleh kawasan lindung cenderung mengakibatkan rasio panjang jalan terhadap luas wilayah menjadi sangat rendah. Hal ini menjadi salah satu kelemahan studi dalam penelitian ini. Namun demikian, penelitian ini cukup menggambarkan adanya korelasi yang menggambarkan pola hubungan antara ketersediaan infrastruktur dengan tingkat kesejahteraan penduduk dan menjadi justifikasi pentingnya infrastruktur transportasi jalan dalam meningkatkan kesejahteraan penduduk.

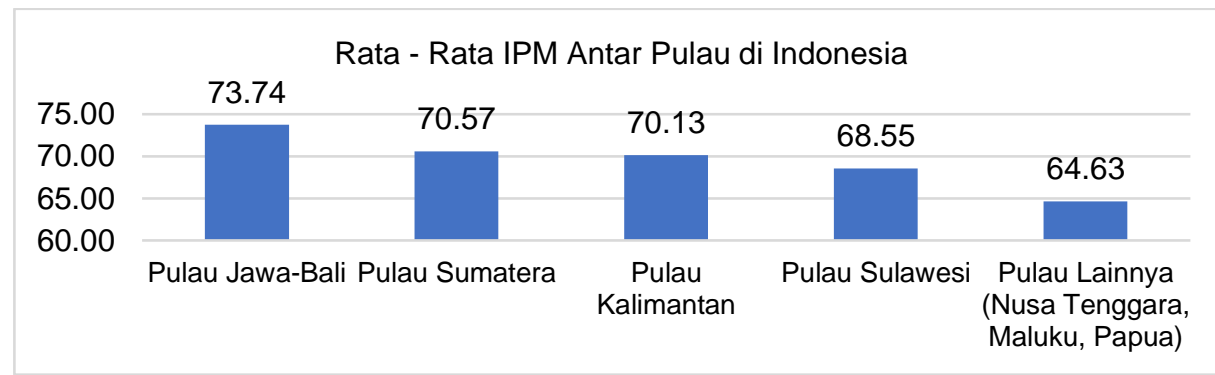

Gambar 4. Rata- Rata Angka IPM Berdasarkan Pulau di Indonesia, 2017 Sumber: Hasil Analisis, 2020

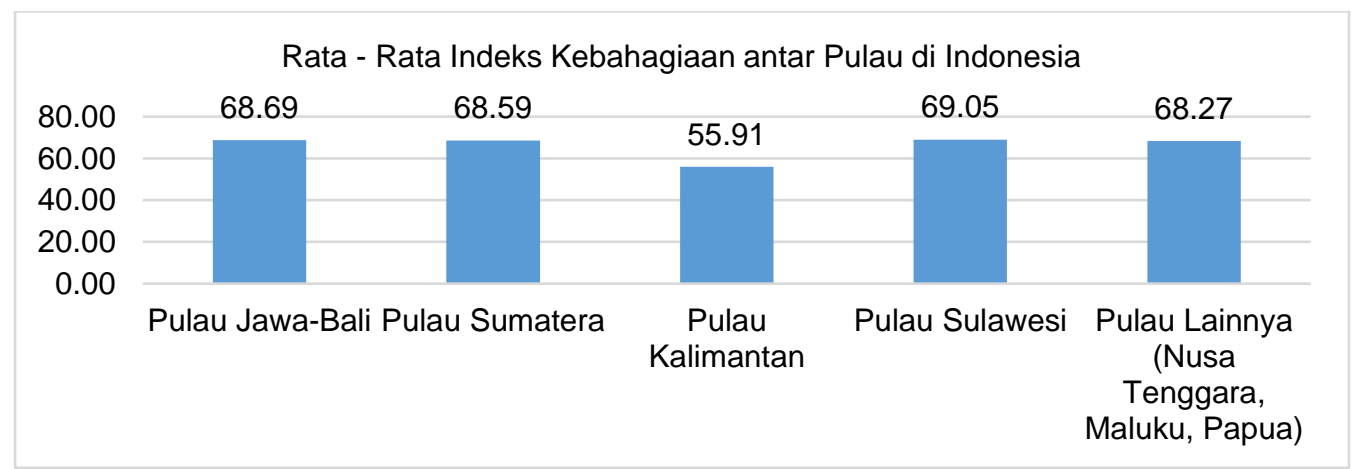

Gambar 5. Rata- Rata Indeks Kebahagiaan Penduduk Berdasarkan Pulau di Indonesia , 2017 Sumber: Hasil Analisis, 2020 
Berbanding terbalik dengan variabel IPM, hasil uji korelasi pearson menunjukkan tidak adanya hubungan antara variabel ketersediaan infrastruktur jalan dengan variabel indeks kebahagiaan. $\mathrm{Hal}$ ini ditunjukkan oleh nilai $r$ statistic $(0,253)$ yang lebih kecil dari nilai $r$ tabel $(0,4357)$ serta nilai signifikansi yang lebih besar dari nilai $\alpha, 0,01$. Jika disandingkan per pulau di Indonesia, indeks kebahagiaan penduduk Indonesia antar pulau cenderung tidak jauh berbeda sebagaimana dituditunjukkan pada Gambar 5. Pulau Jawa-Bali, Pulau Sumatera, Pulau Sulawesi serta Pulau di gugusan Nusa Tenggara, Maluku, dan Papua memiliki rata-rata indeks kebahagiaan yang hampir sama dalam rentang 68 - 69, kecuali Pulau Kalimantan yang memiliki rata-rata indeks kebahagiaan yang relatif lebih rendah dibanding 4 kategori pulau lainnya di Indonesia. Hal ini dapat disimpulkan bahwa kesejahteraan immaterial tidak ditentukan oleh lokasi geografis ataupun ketersediaan infrastruktur jalan. Penduduk yang tinggal di area dengan tingkat konektivitas yang tinggi belum tentu lebih bahagia dibandingkan penduduk yang tinggal di area terpencil dengan tingkat konektivitas yang buruk.

\section{Kesimpulan}

Hasil uji analysis of variance menunjukkan bahwa terdapat perbedaan rata-rata atau terdapat kesenjangan ketersediaan infrastruktur jalan pada setiap kategori pulau di Indonesia. Kesenjangan tidak saja terjadi antar pulau tetapi juga terjadi antar provinsi dalam pulau. Banyak penelitian menunjukkan bahwa ketersediaan infrastruktur jalan akan berpengaruh terhadap tingkat kesejahteraan penduduk (Porter, 2002; Maparu and Mazumder, 2017; Arimah, 2017; Li et al; 2018). Berdasarkan hasil analisis korelasi antara ketersediaan jalan dengan tingkat kesejahteraan penduduk dapat disimpulkan bahwa ketersediaan infrastruktur jalan berkorelasi cukup erat dengan kesejahteraan yang sifatnya materiil dengan arah hubungan positif dimana semakin tinggi ketersediaan jalan cenderung akan meningkatkan konektivitas penduduk terhadap fasilitas pendidikan, fasilitas kesehatan, area perkantoran dan fasilitas perdagangan, sehingga kecenderungan wilayah yang angka rasio ketersediaan jalan terhadap wilayahnya tinggi cenderung memiliki IPM yang tinggi dan demikian sebaliknya.

Hal yang kontras tampak pada kesejahteraan yang sifatnya immaterial, ketersediaan infrastruktur jalan tidak memiliki korelasi dengan kesejahteraan yang sifatnya immaterial seperti tingkat kebahagiaan, dimana penduduk yang tinggal di area yang lebih urbanized dengan ketersediaan infrastruktur jalan yang tinggi tidak selalu memiliki tingkat kebahagiaan yang lebih tinggi dibandingkan penduduk yang tinggal didaerah terpencil. Dengan demikian, untuk konteks kesejahteraan yang sifatnya immateril tidak dapat ditentukan berdasarkan indikator pembangunan infratruktur jalan. Dengan demikian berdasarkan penelitian ini dapat disimpulkan bahwa betul ketersediaan infrastruktur jalan dapat memicu peningkatan kesejahteraan, tetapi hanya dalam konteks kesejahteraan material yang diukur dengan nilai IPM.

Penelitian ini cukup menggambarkan korelasi antara ketersediaan infrastruktur dengan tingkat kesejahteraan penduduk dan menjadi justifikasi empiris pentingnya infrastruktur transportasi jalan dalam meningkatkan kesejahteraan penduduk.

\section{DAFTAR PUSTAKA}

Arimah, B. (2017). Infrastructure as a Catalyst for the Prosperity of African Cities. Procedia Engineering 198 ( 2017 ) 245 $266 . \quad$ doi: 10.1016/j.proeng.2017.07.159

Banister, D and Berechman, J. (2000). Transport Investmend and Economic Development. London: UCL Press

BPS.(2015). Kajian Indikator Lintas Sektor: Potret Awal Pembangunan Pasca MDGs, Sustainable Development Doals (SDGs). ISBN : 978-979-064-940-8

BPS. (2019). Produk Domestik Regional Bruto Provinsi- Provinsi di Indonesia Menurut Pengeluaran 
Tahun 2014 - 2018. ISBN: 25802224

Decleve, S.D and Pereira, C.A. (2019). Redefining Prosperity Discussion Paper: The Time is Now. Published by the Club of Rome on 18 September 2019.

https://www.clubofrome.org/wpcontent/uploads/2019/09/Redefinin g-Prosperity.pdf

Delhey, J and Kroll, C. (2013). A "Happiness Test" for the New Measures of National Well-Being: How Much Better than GDP are They?. Human Happiness and the Pursuit of Maximization pp 191210.

De los Rios, I et al. (2016). Redefining rural prosperity through social learning in the cooperativesector: 25 years of experience from organic agriculture in Spain. Land Use Policy 54 (2016) 85-94

Dipietro, W.R and Anoruo, E. (2006). GDP per capita and its challengers as measures of happiness. International Journal of Social Economics. ISSN: 0306-8293

Firman, T. (2009). The Continuity and Change in Mega-Urbanization in Indonesia: A Survey of JakartaBandung Region (JBR) Development. Habitat International 33 (2009) 327-339. doi:10.1016/j.habitatint.2008.08.00 5

Friedman, J. (2003). How responsive is poverty to growth? A regional analysis of poverty, inequality, and growth in Indonesia, 1984 - 99, WIDER Discussion Paper, No. 2003/57, The United Nations University World Institute for Development Economics Research (UNU-WIDER),

Helsinki Fox, J. (2012). Harvard Business Review. Available at https://hbr.org/2012/01/theeconomics-of-well-being

Healey, J.F. (2012). Statistics: A Tool for Social Research Ninth Edition. Belmont: Wadsworth

Ivanova, E and Masarova, J. (2013). Importance of Road Infrastructure in the Economic Development and Competitiveness. Economics and
Management 2013. 18 (2). ISSN 2029-9338

Indraprahasta, G.S and Derudder, B. (2019). World City-ness in a historical perspective: Probing the long-term evolution of the Jakarta metropolitan area. Habitat International 89 (2019) 102000. https://doi.org/10.1016/j.habitatint. 2019.102000

Kalimeris, P et al. (2020). Hidden linkages between resources and economy: A "Beyond-GDP" approach using alternative welfare indicators. Ecological Economics 169 (2020) 106508.

https://doi.org/10.1016/j.ecolecon. 2019.106508

Kurniawan, D.A and Mulyono, A.T. (2005) . Penyusunan Jaringan Jalan Kota Sebagai Strategi Mengatasi Kemiskinan Kota. Jurnal Transportasi Vol. 5 No. 2 Desember 2005: 147-158

Kusbiantoro, B.S. (2007). Memanusiakan Perencanaan Sistem Transportasi. Bandung: Pusat Penelitian Pengelolaan Lingkungan, Wilayah dan Infrastruktur, Institut Teknologi Bandung.

Kushlev, K et al. (2017). ENHANCE: Design and rationale of a randomized controlled trial for promoting enduring happiness \& well-being. Contemporary Clinical Trials $52 \quad$ (2017) 6274.http://dx.doi.org/10.1016/i.cct.2 016.11 .003

Land KC, Michalos AC. (2018). Fifty years after the social indicators movement: has the promise been fulfilled?: an assessment an agenda for the future. Soc Indic Res. 2018; 135: 835-868. https://doi.org/10.1007/s11205017-1571-y

$\mathrm{Li}, \mathrm{H}$ et al. (2018). Characterizing the relationship between road infrastructure and local economy using structural equation modeling. Transport Policy 61 (2018) 17-25. https://doi.org/10.1016/j.tranpol.20 17.10 .002

Maparu, T.S and Mazumder, T.N. (2017). Transportation Infrastructure, Economic Development and 
Urbanization in India (1990 2011): Is there any Casual Relationship?. Transportation Research Part A 100 (2017) 319336.

http://dx.doi.org/10.1016/j.tra.2017. 04.033

Musa, H.D et al. (2018). Enhancing subjective well-being through strategic urban planning: Development and application of community happiness index. Sustainable Cities and Society 38 (2018) 184-194. https://doi.org/10.1016/i.scs.2017. 12.030

Ortuzar, J. D. and Willumsen, L. G. (2011). Modelling Transport: Fourth Edition. West Sussex. John Wiley and Sons, Ltd.

Pinto, S et al. (2017). Comfort, well-being and quality of life: Discussion of the differences and similarities among the concepts. Porto Biomed. J. 2017;2(1):6-12.

http://dx.doi.org/10.1016/j.pbj.2016 .11 .003

Porter, G. (2002). Living in a Walking World: Rural Mobility and Social Equity Issues in Sub-Saharan Africa. World Development Vol. 30, No. 2, pp. 285-300, 2002.

Talitha, T et al. (2019). Welcoming Two Decades of Decentralization in Indonesia: a Regional Development Perpective. Territory, Politics, Governance. https://doi.org/10.1080/21622671. 2019.1601595

Trkulja, S. (2007). Happiness as Indicator and Planning Objective for the Spatial Development Policy . Available at http://gnh movement.o rg/papers/trkulja.pdf. Joshanloo, $M$ et al. 2019. A multidimensional understanding of prosperity and well-being at country level: Data-driven explorations. PLoS ONE 14(10): e0223221. https://doi.org/10.1371/journal.pon e.0223221

UNDP. (2019). Human Development Report 2019: Beyond income, beyond averages, beyond today: Inequalities in human development in the 21 st century. Available at hdr.undp.org/sites/default/files/hdr 2019.pdf

UN Habitat. (2019). State of the World's Cities 2012/2013: Prosperity of Cities. Available at https://sustainabledevelopment.un. org/content/documents/745habitat. pdf

Wajdi, Nashul et al. (2017). Gravity Model of Interregional Migration in Indonesia. Bulletin of Indonesian Economic Studies, 53:3, 309332.https://doi.org/10.1080/00074 918.2017.1298719

Wong, C. (2015). A framework for 'City Prosperity Index': Linking indicators, analysis and policy. Habitat International 45 (2015) 3e9. http://dx.doi.org/10.1016/j.habitatin t.2014.06.018

Yigitcanlar, T et al. (2015). Towards prosperous sustainable cities: A multiscalar urban sustainability assessment approach. Habitat International 45 (2015) 36e46. http://dx.doi.org/10.1016/j.habitatin t.2014.06.033 